\title{
Evaluation of aqueous Ozone as a method to combat multidrug- resistant Staphylococcus aureus tainting cattle meat sold in Wasit marketplaces
}

\author{
Manal Hadi Ghaffoori Kanaan ${ }^{{ }^{*}}$, Sura Saad Abdullah ${ }^{2}$ \\ ${ }^{1}$ Agriculture Department/ Technical Institute of Suwaria, Middle Technical University, Baghdad, Iraq \\ ${ }^{2}$ Al- Suwaria General Hospital / Wassit Health Office, Wassit, Iraq.
}

\section{ARTICLE HISTORY}

Received: 16.09 .2020

Revised: 06.09.2021

Accepted: 16.09.2021

Corresponding author: Manal Hadi Iraq/manalhadi73@yahoo.com

\begin{abstract}
Objective: To evaluate the effectiveness of ozonation treatment (1/2 ppm for up to $30 \mathrm{~min}$ at 3-7 centigrade) on the persistence of multidrug-resistance Staphylococcus aureus (MDR S. aureus) tainting cattle meat.

Design: Descriptive study

Procedures: Nine testers of cattle's meat including imported $(n=3)$ and locally slaughtered $(n=6)$, which were stored at -18 centigrade and accepted positive for MDR S. aureus were subjected to aqueous ozone $\left(\mathrm{O}_{3}\right)$ as $1 / 2$ ppm for 15 and $30 \mathrm{~min}$.

Results: The results presented that after ozonation treatment (1/2 ppm at 3-7 centigrade), the whole testers which free from MDR S. aureus were $22.2 \%$ \& $55.6 \%$ for 15 \& $30 \mathrm{~min}$, respectively. Additionally, the antimicrobial effectiveness of aqueous $\mathrm{O}_{3}$ as $1 / 2 \mathrm{ppm}$ on the decline of MDR S. aureus level $\left(\log _{10} \mathrm{CFU} / \mathrm{ml}\right)$ was measured against three contaminated testers of cattle's meat. The outcomes publicized that afterward handlings, the total decline of bacterial counts was 2-3 $\log _{10}$ (CFU/ml) after $30 \mathrm{~min}$ at 3-7 centigrade, this decline is extremely noteworthy from the opinion of public health. The effectiveness of aqueous $\mathrm{O}_{3}(0.5$ ppm/3-7 centigrade) with carcass drip to MDR S. aureus was assessed and the results displayed that $77.8 \%$ and $100 \%$ of the testers of aqueous $\mathrm{O}_{3}$ were negative after ozonation treatments for 15 and 30 min, respectively.

Conclusion and clinical relevance: $\mathrm{O}_{3}$ as $1 / 2 \mathrm{ppm}$ is exceedingly active in dropping the amount of MDR S. aureus contaminated testers and this decline augmented as prolonged experience time to ozonation treatment. On the other hand, $\mathrm{O}_{3}$ was highly effective in eradicating MDR S. aureus even in the presence of high levels of organic materials. These outcomes designated $\mathrm{O}_{3}$ as a substitute promising approach to decline meat contagion with foodborne microorganisms for instance MDR S. aureus.
\end{abstract}

Keywords: Antimicrobial resistance, aqueous ozone, cattle's meat, Staphylococcus aureus, Wasit province.

\section{INTRODUCTION}

Meat can be tainted with a wide variety of pathogenic and spoilage microorganisms during the periods of slaughter, processing, and storage. In addition, it was considered one of the most important sources of foodborne pathogens [1]. Among these pathogens, S. aureus has mentioned as a celebrated opportunistic foodborne bacterium, which considered as a hazard due to its harmful effects on animal health and its ability to transmit from animals to humans and vice versa [2]. It is among the most prevalent causes of clinical infections globally and has garnered substantial public attention due to increasing mortality associated with MDR [3]. Multidrug-resistant S. aureus has been established in different meat-generating animals internationally [4]. The occurrence of livestockassociated MRSA in farmhouse animals is cumulative that lead to increase likelihood contamination of the food products [5]. Numerous researchers have perceived the universality of the isolation of MDR Staphylococci from meat testers [6-9]. This must be taken seriously, especially when the discovery of Waters et al. [3] documented that about $50 \%$ of grocery supplies with meat testers experienced in the United States are tainted by MDR S. aureus for not less than three classes of antimicrobials.

To eliminate bacterial contaminants in meat numerous sanitizing interventions as well as treatments were developed via food manufacturing including washing by acid and salts [10], the use of chlorine dioxide [11], irradiation with gamma-rays [12], ultraviolet radiation and $\mathrm{O}_{3}$ [13]. The use of chlorine is becoming more scrutinized because of toxicity issues and disinfection by-products that have proven harmful from the point of view of food and environmental safety [14]. Food researchers are seeking to discover a substitute agents used for cleanliness and sanitation characterized by their effectiveness to foodborne bacteria, inoffensive to human being and environment [15]. Recently, $\mathrm{O}_{3}$ has been attracted the attention of food scientists as an alternative sanitizer [16], as of its influential disinfecting 
effectiveness, this gas can be practical use in the food manufacturing to eradicate bacteria plus to incapacitate viruses, fungi as well as their toxins [17]. On the other hand, there is no any detrimental deposits in/on products following ozonation, as it rapidly rots to $\mathrm{O}_{2}$ [18]. Ozone usage has augmented due to its description as Generally Recognized as Safe (GRAS) by the Ministry of Food and Drug Safety (MFDS) in 1997 [19]. Ozone has been documented to eradicate foodborne microorganisms for instance Salmonella, Listeria monocytogenes and S. aureus [13]. Consequently, $\mathrm{O}_{3}$ is measured to be greatest suitable method aimed at removing microbes of food protection concern [20].

In our country, cattle's meat is measured as the greatest widespread meat item in numerous populations and if we consider that when cooking meat, it is extremely important to disinfect the produce completely in order to eradicate foodborne pathogens such as S. aureus, so this study was conducted to assess the effects of $\mathrm{O}_{3}$ treatment on the microbiological security of such products that have been retailed in the marketplaces of Wasit governorate.

\section{MATERIALS AND METHODS}

\subsection{Ethical Approval}

Meat samples were obtained from the markets, so there is no need for such approval.

\subsection{Treating of samples}

A total of nine samples including imported $(n=3)$ and locally slaughtered cattle's meat $(n=6)$, which were stored at -18 centigrade and accepted positive for MDR S. aureus using ordinary microbiological and biochemical exams and confirmed via Rapid 'm Staph Plus system (Remel, R8311009), latex agglutination kit Dry SPOT Staphytect Plus (Oxoid, DR0100M) and rapid latex agglutination assessment PBP2a kit (Oxoid, DR0900A) as pronounced earlier [21]. These samples distributed into two portions, the first one exposed to aqueous $\mathrm{O}_{3}$ for 15 and $30 \mathrm{~min}$ using Aqua- $6 \mathrm{O}_{3}$ originator $(600 \mathrm{mg} / \mathrm{h})$, while the second parts were stored at -18 centigrade for additional scrutiny.

\subsection{Calculation of $\mathrm{O} 3$ concentration output}

The concentration of $\mathrm{O}_{3}$ generated by the Aqua6 originator in water as ppm was done by CHE-Mets ${ }^{\circledR}$-Kit as a way applied by [22]. In brief, A plastic tub was filled with water and covered with its lid, then aeration stone was implanted into the tub via a hole in the lid. Four experience times were taken $(5,10,15$ and $30 \mathrm{~min})$. Next every experience, the water was altered, and the procedure was recurrent. To determine $\mathrm{O}_{3}$ concentration in water five drops of A-7400 Activator were added into the empty sample cup then filled to the $25 \mathrm{ml}$ mark with the aqueous $\mathrm{O}_{3}$, then the CHE Met ampoule tip was placed into the cup and, the tip of the ampoule was broke. The ampoule was filled by the aqueous $\mathrm{O}_{3}$, then upturned numerous times to mix comprehensively and dried by left for $1 \mathrm{~min}$ for color development. The ampoule was positioned among the color values till the top color was corresponding using High Range comparator [22]. The peak concentration among the experiences used was obtained at 15 and $30 \mathrm{~min}$, which was $1 / 2 \mathrm{ppm}$ in water (Figure 1).

\subsection{The effect of aqueous 03 on MDR S. aureus}

The first part of every sample was subjected to ozonation. In this experiment $\mathrm{O}_{3}$ gas was inserted into the water using aeration stone (Diffuser) and disseminated it consistently all over the water. The Aqua- 6 originator was fed with $1 \mathrm{~L} / \mathrm{min}(600 \mathrm{mg} / \mathrm{hr}$ ) of beaten air as a feed gas. The testers were defrosted at 4 centigrade for $18 \mathrm{~h}$, then dipped into aqueous $\mathrm{O}_{3}$ at 3-7 centigrade to allow dispersion of $\mathrm{O}_{3}$ within the samples for two different experience times (15 and $30 \mathrm{~min}$ ) in order to evaluate the effect of ozonation on MDR S. aureus (Figure 2).

A slice of $(25 \mathrm{gm})$ of every treated tester was sliced and processed in a stomacher with $225 \mathrm{ml}$ of buffered peptone water for $2 \mathrm{~min}$, then $10 \mathrm{ml}$ of the homogenate was mixed with $100 \mathrm{ml}$ of Tryptone soy broth-yeast extract (TSB$\mathrm{YE}), 10 \% \mathrm{NaCl}$ and $1 \%$ sodium pyruvate. After incubation at 35 centigrade for $18 \mathrm{~h}, 20 \mu \mathrm{l}$ of the culture was plated on Baird-Parker agar (Oxoid, CM1127) supplemented with egg yolk tellurite and incubated overnight at 37 centigrade as described previously [21].

Of the nine second parts three samples (local cattle $1^{\text {st }}$, local cattle $2^{\text {nd }}$ and imported cattle $\left.1^{\text {st }}\right)$ were taken to assess the effectiveness of aqueous $\mathrm{O}_{3}$ on the decline of MDR S. aureus count $\left(\log _{10} / \mathrm{ml}\right)$ after conducts for 15 and $30 \mathrm{~min}$ at 3-7 centigrade. First, these samples were processed as described previously to detect the initial bacterial count, then subjected to ozonation for two experience times and possessed after each experience. Miles and Mizra technique [23], was adopted to detect the influence of ozonation on MDR S. aureus through estimated the sum of colony forming units (CFU) in a bacterial broth in which a series of decimal ten dilution of enrichment broths were diluted with sterile BPW tubes ( $1 \mathrm{ml}$ broth / 9ml BPW), dilutions were made to at least $10^{-8}$, then $5 \times 20 \mu$ of each dilution were dropped onto surface of the Baird-Parker agar and allowed to spread and dry naturally before inversion and incubation at 37 centigrade for $24 \mathrm{~h}$. The colonies were counted in the drops where the highest number of full-size discrete colonies were seen (usually drops containing between 10-20 colonies were counted). The microbial load $\log _{10}$ titers were adjusted by the low of Miles and Mizra [23].

CFU per $\mathrm{ml}=$ Average number of colonies for a dilution $\times 50$ $x$ dilution factor [23].

\subsection{Detection the effectiveness of aqueous 03 with meat drip against MDR S. aureus}

One $\mathrm{ml}$ of aqueous $\mathrm{O}_{3}$ for all samples was injected to 5 $\mathrm{ml}$ of (double strength) Trypton Soya Broth (Oxoid, CM0129) with $0.6 \%$ Yeast Extract (TSB-YE) and incubated at 35 centigrade for $18 \mathrm{~h}$, then $20 \mu \mathrm{L}$ of the culture was plated 
onto Baird-Parker agar (Oxoid, CM1127) improved with egg yolk tellurite then incubated overnight at 37 centigrade.

\subsection{Statistics}

Analysis of data were implemented by MedCalc Software bvba version 18 (BE,USA). Two samples Chi-square $(\chi 2)$ between proportions was implemented to evaluate significance between proportions with a $5 \%$ significant level https://www.medcalc.org/.

\section{RESULTS}

In this study the effectiveness of aqueous $\mathrm{O}_{3}$ against MDR S. aureus contaminating cattle's meat was inspected and the obtainable results are set in Table 1 . The results showed that after treatment with aqueous $\mathrm{O}_{3}(1 / 2 \mathrm{ppm} / 15$ $\min$ ), two testers $(22.2 \%)$ were free (no growth on agar surface) besides seven testers $(77.8 \%)$ were positive (more than 100 colonies / plate). While, when experience time was delayed to $30 \mathrm{~min}$, five samples (55.6\%) were negative, and four samples (44.4\%) were positive (less than 40 colonies / plate). Statistically there is no significant effect ( $p>0.05)$ for the experience times ( 15 and $30 \mathrm{~min}$ ) on the effectiveness of aqueous $\mathrm{O}_{3}$ at the same concentration $(1 / 2 \mathrm{ppm})$ against MDR S. aureus tainting cattle's meat $\left(\chi^{2}=1.995, p=0.158\right)$.

Table 1. Effect of aqueous ozone (0.5 ppm) for 15 and 30 min on MDR $S$. aureus tainting cattle's meat.

\begin{tabular}{|c|c|c|c|}
\hline $\begin{array}{l}\text { Source } \\
\text { cattle's }\end{array}$ & $\begin{array}{l}\text { Total } \\
\text { No.tve }\end{array}$ & \multicolumn{2}{|c|}{$\begin{array}{l}\text { Total No.-ve for MDR S. aureus after } \\
\text { ozone treatment (\%) }\end{array}$} \\
\hline & & 15 minutes & 30 minutes \\
\hline Local & 6 & $1(16.7 \%)$ & $3(50 \%)$ \\
\hline Imported & 3 & $1(33.3 \%)$ & $2(66.7 \%)$ \\
\hline Total & 9 & 2 & 5 \\
\hline \multicolumn{2}{|c|}{ Effectiveness (-ve) } & $2 / 9(22.2 \%)$ & $5 / 9(55.6 \%)$ \\
\hline
\end{tabular}

Table 2. Antibacterial effectiveness of aqueous ozone $(0.5 \mathrm{ppm})$ for 15 and $30 \mathrm{~min}$ on the reduction of MDR S. aureus count ( $\log 10$ / $\mathrm{ml}$ ) for three positive samples.

\begin{tabular}{|c|c|c|c|c|c|c|}
\hline \multirow{2}{*}{$\begin{array}{l}\text { Sample's } \\
\text { code }\end{array}$} & \multirow{2}{*}{$\begin{array}{l}\log _{10} / \mathrm{ml} \\
\text { count } \\
\text { before } \\
\text { ozone } \\
\text { treatment }\end{array}$} & \multicolumn{5}{|c|}{$\log _{10} / \mathrm{ml}$ count after ozone treatment } \\
\hline & & $\begin{array}{l}15 \\
\min .\end{array}$ & $\begin{array}{l}\log _{10} \\
\text { Decre- } \\
\text { ased }\end{array}$ & $\begin{array}{l}30 \\
\min .\end{array}$ & $\begin{array}{l}\log _{10} \\
\text { Decre- } \\
\text { ased }\end{array}$ & $\begin{array}{l}\text { Total } \\
\log _{10} \\
\text { Decre- } \\
\text { ased }\end{array}$ \\
\hline $\begin{array}{l}\text { Local } \\
\text { cattle 1st }\end{array}$ & $1.2 \times 10^{5}$ & $\begin{array}{l}1.1^{3} \times \\
10^{3}\end{array}$ & 2 & $\begin{array}{l}1.1 \times \\
10^{2}\end{array}$ & 1 & 3 \\
\hline $\begin{array}{l}\text { Local } \\
\text { cattle } \\
\text { 2nd }\end{array}$ & $1.4 \times 10^{6}$ & $\begin{array}{l}1.4 \times \\
10^{5}\end{array}$ & 1 & $\begin{array}{l}1.3 \times \\
10^{4}\end{array}$ & 1 & 2 \\
\hline $\begin{array}{l}\text { Imported } \\
\text { cattle } 1 \mathrm{st}\end{array}$ & $1.7 \times 10^{4}$ & $\begin{array}{l}1.7^{\times} \times \\
10^{3}\end{array}$ & 1 & $\begin{array}{l}1.6 \times \\
10^{2}\end{array}$ & 1 & 2 \\
\hline
\end{tabular}

Table 3. The effectiveness of aqueous ozone (0.5 ppm) contained meat drip against MDR $S$. aureus after treatments of cattle's meat for 15 and $30 \mathrm{~min}$.

\begin{tabular}{|c|c|c|c|}
\hline $\begin{array}{l}\text { Source } \\
\text { cattle's } \\
\text { meat }\end{array}$ & $\begin{array}{l}\text { No. of } \\
\text { samples } \\
\text { tested }\end{array}$ & \multicolumn{2}{|c|}{$\begin{array}{l}\text { Effectiveness of aqueous ozone ( } 0.5 \\
\text { ppm) }\end{array}$} \\
\hline Local & 6 & $5(83.3 \%)$ & $6(50 \%)$ \\
\hline Imported & 3 & $2(66.7 \%)$ & $3(66.7 \%)$ \\
\hline Total & 9 & 7 & 9 \\
\hline & & $7 / 9(77.8 \%)$ & $9 / 9(100 \%)$ \\
\hline
\end{tabular}

The effectiveness of aqueous $\mathrm{O}_{3}(1 / 2 \mathrm{ppm})$ on the decline of MDR S. aureus count $\left(\log _{10} / \mathrm{ml}\right)$ was experienced using two experience times (15 and $30 \mathrm{~min}$ ) and the acquired data is given in Table 2. Our outcomes indicated that the bacterial counts before treatments were $\left(1.2 \times 10^{5}\right)$ , $\left(1.4 \times 10^{6}\right)$ and $\left(1.7 \times 10^{4}\right)$ for local cattle $1^{\text {st }}$, local cattle $2^{\text {nd }}$ and imported cattle $1^{\text {st }}$, respectively. Whereas after ozonation for $15 \mathrm{~min}$ these counts were declined to reach $\left(1.1 \times 10^{3}\right),\left(1.4 \times 10^{5}\right)$ and $\left(1.7 \times 10^{3}\right)$ for local cattle $1^{\text {st }}$, local cattle $2^{\text {nd }}$ and imported cattle $1^{\text {st }}$, respectively. And this decline was further increased when experience time was prolonged to $30 \mathrm{~min}$ to reach $\left(1.1 \times 10^{2}\right),\left(1.3 \times 10^{4}\right) \&(1.6 \times$ $\left.10^{2}\right)$ for local cattle $1^{\text {st }}$, local cattle $2^{\text {nd }}$ and imported cattle $1^{\text {st }}$ , respectively.
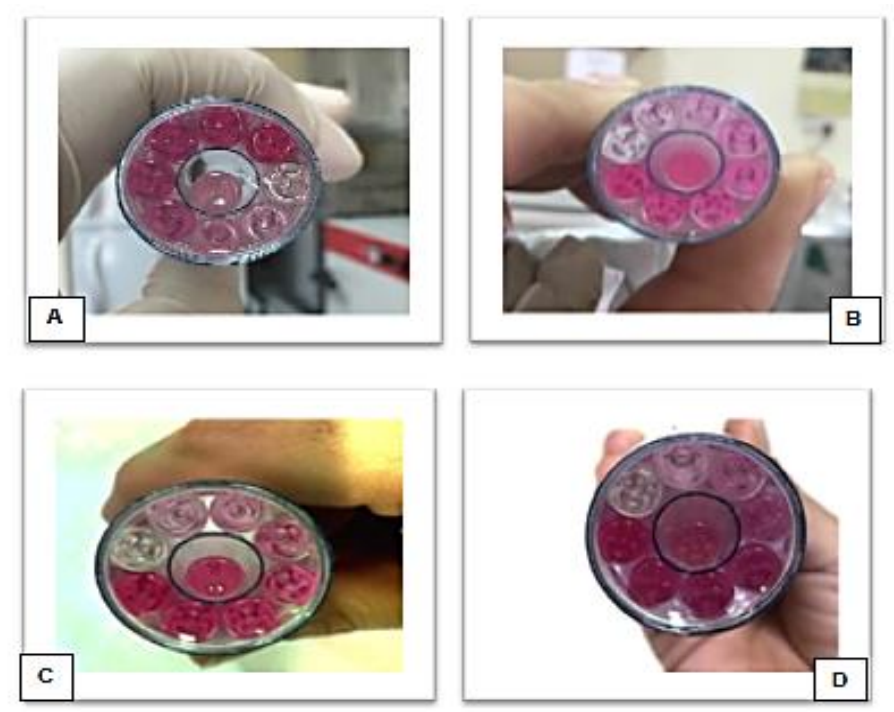

Figure 1. A, B, C, and D: ozone concentration output (ppm/in water) of the ozone originator at diverse experience times: (A) : for $5 \mathrm{~min}$; (B) : for 10 $\mathrm{min}$; (C) : for $15 \mathrm{~min}$, and (D) : for $30 \mathrm{~min}$. 


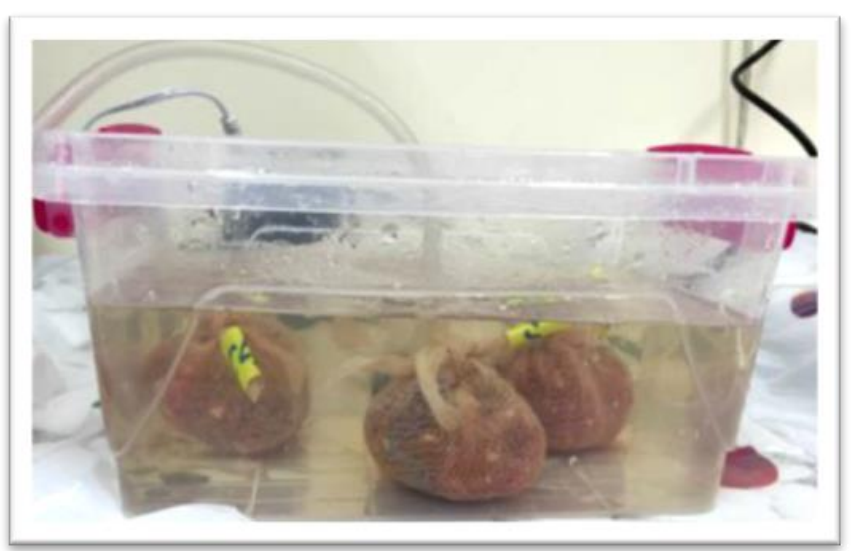

The effectiveness of aqueous $\mathrm{O}_{3}(0.5 \mathrm{ppm})$ contained meat drip against MDR S. aureus was evaluated and the results displayed that $77.8 \%$ and $100 \%$ of the testers of aqueous $\mathrm{O}_{3}$ were free (no growth on agar surface) after treatments of cattle's meat for 15 and $30 \mathrm{~min}$, respectively (Table 3). Statistically there is no significant effect $(p>0.05)$ for the experience times (15 and $30 \mathrm{~min}$ ) on the effectiveness of aqueous $\mathrm{O}_{3}$ containing organic materials at the same concentration $(1 / 2 \mathrm{ppm})$ against MDR S. aureus $\left(\chi^{2}=2.123\right.$, $\mathrm{p}=0.145)$.

\section{DISCUSSION}

Ozone is the perfect solution for beef processing industry, it has been used for plant cleaning, disinfecting, and sanitizing due to its extraordinary oxidation possessions that conveys microbicides properties [24]. The outcomes (Table 1 ) showed that $22.2 \%$ and $55.6 \%$ of samples were negative after treatment with aqueous $\mathrm{O}_{3}$ for 15 and $30 \mathrm{~min}$, respectively. Moreover, the results (Table 2) also revealed that a total reduction as $2-3 \log _{10} / \mathrm{ml}$ in the levels of MDR S. aureus was achieved through ozonation treatment of meat for $30 \mathrm{~min}$.

Eradication of microorganisms via $\mathrm{O}_{3}$ can be linked to its highly un stability which lead to its rapidly decompose into free radicals, so the effectiveness of $\mathrm{O}_{3}$ is attributed to the oxidizing influence of these free radicals, its capability to diffuse over biotic membranes, then destroying pathogens by attacking and oxidizing the cell walls of the organism and continue to break molecular chain down until it's nothing but carbon dioxide and water $[25,26]$.

The outcomes of this experiment directed that the sum of surviving microbial cells symbolized by CFU from testers after ozonation treatment were less than from untreated samples. As well as the number decreased with increasing the experience time at the same concentration (1/2 ppm), reasonable clarification possibly due to increasing the experience time lead to longer the contact time of ozone with microorganisms, leading to lower inactivation rate. Besides, $\mathrm{O}_{3}$ treatments were done at 3-7 centigrade, and in general the antimicrobial activity of $\mathrm{O}_{3}$ decreased with increasing temperatures. So, when a temperature of aqueous medium decreases this will lead to increasing $\mathrm{O}_{3}$ solubility and stability, enhancing its availability in the medium and consequently efficacy rises [26].

The effectiveness of $\mathrm{O}_{3}$ to advance the microbial quality of meat had formerly been well-known by Cárdenas et al. [17] who found that gaseous $\mathrm{O}_{3}$ as $154 \times 10^{-6} \mathrm{~kg} \mathrm{~m}^{-3}$ at $0-4$ centigrade for $3 \mathrm{~h}$ reduced total aerobic mesophilic heterotrophic microorganisms and Escherichia coli on beef testers by $0.5 \log _{10}$ and 0.6 - $1.0 \log _{10}$ cycles, respectively. Reagan et al. [27] established that aqueous $\mathrm{O}_{3}$ as 0.3 to 2.3 ppm reduced aerobic plate counts by $1.30 \log _{10} \mathrm{CFU} / \mathrm{cm}^{2}$ and concluded that ozonation treatment can be used as suitable intervention for removing physical and bacterial contamination from beef carcasses. Another study conducted by Novak and Yuan [28], to determine the effect of aqueous $\mathrm{O}_{3}$ treatment as 3 ppm for 5 min on the survival of three-strain cocktails of Clostridium perfringens, Escherichia coli 0157:H7 (E. coli O157:H7), and Listeria monocytogenes on beef surfaces, they found that reductions following treatment were $1.28,0.85$, and 1.09 $\log _{10} \mathrm{CFU} / \mathrm{g}$, respectively. Castillo et al. [29] found that water wash followed by a spray of $\mathrm{O}_{3}$ solution as $95 \mathrm{mg} / \mathrm{L}$ for $30 \mathrm{~s}$ at $80 \mathrm{lb} / \mathrm{in}^{2}$ reduced E. coli 0157:H7 and Salmonella Typhimurium by 2.0 - 3.6 and 1.9 - $3.6 \log _{10} \mathrm{CFU} / \mathrm{cm}^{2}$, respectively. Novak and Yuan [30] concluded that $\mathrm{O}_{3}$ treatment of beef surfaces enhanced the effectiveness of cooking temperatures against enterotoxin-producing strains of Clostridium perfringens in which the vegetative cells on beef surfaces were reduced from $5.59 \pm 0.17 \log _{10} \mathrm{CFU} / \mathrm{g}$ to $4.09 \pm 0.72 \log _{10} \mathrm{CFU} / \mathrm{g}$ and $3.50 \pm 0.90 \log _{10} \mathrm{CFU} / \mathrm{g}$ after combined treatments of aqueous $\mathrm{O}_{3}$ as $5 \mathrm{ppm}$ and subsequently heating at 45 and 55 centigrade, respectively. Cho et al. [31] found that $\mathrm{O}_{3}$ as $10 \times 10^{-6} \mathrm{~kg} \mathrm{O3} \mathrm{h}^{-1}$ at $4^{\circ} \mathrm{C}$ for 1 day reduced the original concentrations of $\mathrm{E}$. coli $\mathrm{O} 157: \mathrm{H7}$ in the inoculated ground beef samples by $0.53 \log _{10} \mathrm{CFU} / \mathrm{g}$ and concluded that $\mathrm{O}_{3}$ continuously eradicated $\mathrm{E}$. coli 0157:H7 on the surface of the beef testers and it can be an antibacterial substance for meat produces in a refrigerator.

The effectiveness of $\mathrm{O}_{3}$ as an intervention against $\mathrm{S}$. aureus and MDR S. aureus was previously established by Kammer [32] who found that the killing effect of $\mathrm{O}_{3}$ is highly dependent on the relative humidity when examine the effect of $\mathrm{O}_{3}$ treatment on S. aureus by which $92 \%$ and $0 \%$ of S. aureus were survived after exposure to gaseous $\mathrm{O}_{3}$ as 0.3 ppm for $1 \mathrm{~h}$ with relative humidity of 15-25 and 85-95, respectively. Also, concluded that $\mathrm{O}_{3}$ is a potent decontaminating agent and has a good potential for use as an agent for disinfection and sterilization. Another study conducted by de Boer et al. [33] who using $\mathrm{O}_{3}$ as an intervention against methicillin resistant $\mathrm{S}$. aureus (MRSA) contaminated home environment of a colonized hospital employee to eradicate these bacteria from a carrier with eczema and they pronounced $\mathrm{O}_{3}$ in gaseous phase as an efficacious intervention to eradicate MRSA from a widely contaminated home environment. Burgassi et al. [34] 
evaluated the bactericidal effect of different concentrations of $\mathrm{O}_{3}$ when used as a gas, or dissolved in saline on $\mathrm{S}$. aureus, MRSA and Pseudomonas aeroginosa that suspended in their culture media, and they found that no viable bacteria of (S. aureus and MRSA) were noticed after $\mathrm{O}_{3}$ exposure as 5 to $320 \mathrm{mg} / \mathrm{L}$ for $15 \mathrm{~min}$ at 20 centigrade. Song et al. [35] in their experiment measured the efficacy and care of current $\mathrm{O}_{3}$ on the cure of skin contagion with MRSA, and they stated that ozonated oil can fumigate up to $98 \%$ of $\mathrm{S}$. aureus and MRSA in 5 and $15 \mathrm{~min}$, respectively. Also, they recorded that aqueous $\mathrm{O}_{3}(1 \mathrm{mg} / \mathrm{L})$ can sterilize $100 \%$ of $\mathrm{S}$. aureus and MRSA in $1 \mathrm{~min}$. Most recently, Kanaan [22] reported that ozonation treatment as $(0.5 \mathrm{ppm})$ for $45 \mathrm{~min}$ of chicken meat resulted in 2-4 log reductions of MRSA.

The results showed that $77.8 \%$ and $100 \%$ of the samples of aqueous $\mathrm{O}_{3}$ were free (no growth on agar surface) after treatments of cattle's meat for 15 and $30 \mathrm{~min}$, respectively (Table 3 ). The results of this study showed that aqueous $\mathrm{O}_{3}$ were successfully killed MDR S. aureus in the presence of meat drip due to powerful oxidizing power of ozone lead to highly ozone's reactivity that make it much more efficient and effective for sterilization of all form of bacteria and viruses in potable water, another advantage provided adequate microbiological controls are implemented, is that the aqueous $\mathrm{O}_{3}$ that has been used for disinfection can potentially be re-used for the initial cleaning stages, either directly or after re ozonation to attain the required quality.

In principle, the outcomes of this experiment agreed with the outcomes obtained by Strasser et al. [36] who found considerable reduction of total bacterial count and complete removal of pathogens when eviscerated chickens treated with aqueous $\mathrm{O}_{3}$ as $4-12 \mathrm{ppm}$ at 4 centigrade for 30 min and concluded that properly filtered chiller water can be safely recycled, saving water and energy. The results of this study were also agreed with Graham et al. [37] who concluded that chiller overflow water using for pre-washing of chicken carcasses with $\mathrm{O}_{3}$ as 4 - 8 ppm could be reconditioned after filtration, as well as they demonstrated that $\mathrm{O}_{3}$ treatment and filtration of chiller water led to elimination of pathogens including Campylobacter, Clostridium perfringens, and Staphylococcus. They also stated that pilot chiller bath water at $4^{\circ} \mathrm{C}$ maintained at $2-4$ ppm ozone remained clear and microbial counts were equivalent to a commercial three - stage chlorinated chiller. Additionally, Kanaan [38] found that that ozonated water as $0.5 \mathrm{ppm}$ were $100 \%$ negative (no bacterial growth on agar surface) for Campylobacter jejuni after treatments of chicken carcasses for 30 and $60 \mathrm{~min}$ at 4 centigrade in the presence of residual protein, fat, and blood. Also, she concluded that the effectiveness of $\mathrm{O}_{3}$ did not affect by the presence of organic materials.

\section{Conclusion}

Based on the defined conditions, the attainable data of our study concluded that $\mathrm{O}_{3}$ is exceedingly effective against MDR S. aureus positive samples and this effectiveness increase with increasing the experience time to ozonation treatment at the same concentration, these findings are greatly significant from the public health perspective. As well as the effectiveness of aqueous $\mathrm{O}_{3}(1 / 2 \mathrm{ppm})$ did not affect by the presence of meat drip and was extremely efficient in excluding MDR S. aureus after treatments of meat for 15 and $30 \mathrm{~min}$. These outcomes suggested the plausible usage of aqueous $\mathrm{O}_{3}$ as a promising alternative involvement to disinfect meat products in order to eliminate common foodborne bacteria such as S. aureus either at abattoirs or prior cooking at home and restaurants.

\section{Authors' Contributions}

The laboratory work involved in this study, organize, writing and revising the manuscript was attained by MHGK. Analysis of data and interpretation of the results was attained by SSA. All researchers have read and approved the final version of the manuscript.

\section{Acknowledgments}

The article was written and supported via the researchers.

\section{Conflict of Interest}

The researchers pronounce they do not have any conflict of interest.

\section{REFERENCES}

[1] Ayranci U G, Ozunlu O, Ergezer H, Karaca H. Effects of Ozone Treatment on Microbiological Quality and Physicochemical Properties of Turkey Breast Meat. Ozone: Scienc Engineering 2019; 1-9. https://doi.org/10.1080/01919512.2019.1653168

[2] Peton V, Le Loir, Y. Staphylococcus aureus in veterinary medicine. Infect Gen Evol 2014 21: 602-615. https://doi.org/10.1016/j.meegid.2013.08.011

[3] Waters A E, Contente-Cuomo T, Buchhagen, J, Liu CM , Watson L, Pearce K, Foster JT, Bowers J, Driebe EM, Engelthaler D.M, Keim, PS, Price, L.B.(2011). Multidrug-Resistant Staphylococcus aureus in US Meat and Poultry. Clin Infect Dis 2011; 52:1227-1230. https://doi.org/10.1093/cid/cir181

[4] Hasman H, Moodley A, Guardabassi, L, Stegger M, Skov RL, Aarestrup, FM. Spa type distribution in Staphylococcus aureus originating from pigs, cattle and poultry. Vet Microbiol 2010; 141:326-31. https://doi.org/10.1016/j.vetmic.2009.09.025

[5] Verhegghe M, Crombé F, Luyckx K, Haesebrouck F, Butaye P, Herman L et al. Prevalence and genetic diversity of livestock-associated methicillin-resistant Staphylococcus aureus on Belgian pork. J Food Prot 2016 79: 82-89. https://doi.org/10.4315/0362-028X.JFP-15-266

[6] Khan S A, Nawaz M S, Khan A A, Hopper S L, Jones R A, Cerniglia CE Molecular characterization of multidrug-resistant Enterococcus spp. from poultry and dairy farms: detection of virulence and vancomycin resistance gene markers by PCR. Molecular and cellular probes 2005; 19: $27-34$

[7]Uber H, Ziegler D, Pflüger V,Vogel G, Zweifel C,Stephan R. Prevalence and characteristics of methicillin-resistant coagulase- negative staphylococci from livestock, chicken carcasses, bulk tank milk, minced meat, and contact persons. BMC Vet Res 2011; 7:6. https://doi.org/10.1186/1746-6148-7-6

[8] Bhargava K, Zhang Y. Characterization of methicillin-resistant coagulasenegatives staphylococci (MR Co NS) in retail meat. Food Microbiol 2014; 42:56e60. https://doi.org/10.1016/j.fm.2014.02.019

[9] Guran H. S, Kahya, S. Species Diversity and Pheno-and Genotypic Antibiotic Resistance Patterns of Staphylococci Isolated from Retail Ground Meats.J Food Sci 2015; 80: M1291-M1298. https://doi.org/10.1111/1750-3841.12893

[10] Latha C, Sherikar AT, Waskar, VS, Dubal, ZB, Ahmed SN. Sanitizing effect of salts on experimentally inoculated organisms on pork 
$\begin{array}{llll}\text { carcasses. Meat } \quad \text { science } & \text { 2009; } & \text { 83, }\end{array}$ https://doi.org/10.1016/j.meatsci.2009.08.033

[11] Lu Y, Wu, C. Reductions of Salmonella enterica on chicken breast by thymol, acetic acid, sodium dodecyl sulfate or hydrogen peroxide combinations as compared to chlorine wash. International journal of food microbiology 2012 152: 31-34. https://doi.org/10.1016/j.ijfoodmicro.2011.09.015

[12] Jouki, M. Evaluation of gamma irradiation and frozen storage on microbial load and physico-chemical quality of turkey breast meat. Radiation Physics and Chemistry 2013; 85: 243-245. https://doi.org/10.1016/j.radphyschem.2012.12.009

[13] Cho Y, Choi JH, Hahn TW, Lee SK. Bacterial Counts and Oxidative Properties of Chicken Breast Inoculated with Salmonella Typhimurium Exposed to Gaseous Ozone. J Food Saf 2015; 35, 137-144. https://doi.org/10.1111/jfs.12161

[14] Kronn TG. Non thermal Plasma Treatment of Packaged Broiler Breast Fillets to Reduce Natural Microflora and Campylobacter jejuni. MSC thesis College of Science / University of Georgia. 2013. https://doi.org/10.21608/avmj.2013.171033

[15] EL Dahshan HA, Hafez TA, EL Ghayaty HA. Effect of Ozone on Preservation of Chilled Chicken. Assiut Vet Med J 2013; 59: 22-26.

[16] Khadre MA, Yousef AE, KIM JG. MicrobioLog10ical Aspects of Ozone Applications in Food: A Review. J Food Sci 2001; 66: 1242-1252. https://doi.org/10.1111/j.1365-2621.2001.tb15196.x

[17] Cardenas FC, Andres S, Giannuzi L, d Zaritzky N. Antimicrobial action and effects on beef quality attributes of a gaseous ozone treatment at refrigeration temperatures. Food Control 2011 22: 1442-1447. https://doi.org/10.1016/j.foodcont.2011.03.006

[18] Wani S, Maker JK, Thompson JR., Barnes J,Singleton I. Effect of Ozone Treatment on Inactivation of Escherichia coli and Listeria spp. on Spinach. Agriculture 2015; 5 :155-169. https://doi.org/10.3390/agriculture5020155

[19] Kim JG,Yousef AE, Dave S. Application of Ozone for Enhancing the Microbiological Safety and Quality of Foods: A Review, J Food Saf 1999; 62 :1071-1087. https://doi.org/10.4315/0362-028X-62.9.1071

[20] Gabler FM, Smilanick JL, Mansour MF, Karaca H. Influence of fumigation with high concentrations of ozone gas on post -harvest gray mold and fungicide residues on table grapes. Postharvest Boil Technol $2010 \quad 55: 85-90$ https://doi.org/10.1016/j.postharvbio.2009.09.004

[21] Kanaan MH G, Al-Isawi AJO. Prevalence of Methicillin or Multiple Drugresistant Staphylococcus Aureus In Cattle Meat Marketed In Wasit Province. Biochem. Cell. Arch 2019; 19: 495-502.

[22] Kanaan MH.. Antibacterial effect of ozonated water against methicillinresistant Staphylococcus aureus contaminating chicken meat in Wasit Province, Iraq. Vet World 2018;11:1445. https://doi.org/10.14202/vetworld.2018.1445-1453

[23] Miles AA, Misra SS. The estimation of the bactericidal power of the blood. J Hyg 1938; 38: 732-749. https://doi.org/10.1017/S002217240001158X

[24] Greene AK, Guzel-Seydim Z B, Seydim AC. Chemical and physical properties of ozone. In: Ozone in food processing. Blackwell Publishing, Ltd., Oxford 2012; pp. 1932 https://doi.org/10.1002/9781118307472.ch3

[25] Smith TC. ,Pearson N..The emergence of Staphylococcus aureus ST398. Vector Borne Zoonotic Dis 2011; 11:327-39. https://doi.org/10.1089/vbz.2010.0072
[26] Patil S. Efficacy of ozone and ultrasound for microbial reduction in fruit juice. Doctoral Dissertation, College of Sciences and Health/ Dublin Institute of Technology 2020.

[27] Reagan JO, Acuff G R, Buege DR, Buyck MJ, Dickson JS, Kastner CL, Marsden JL, Morgan JB, Nickelson RII, Smith GC, John N, Sofos JN. Trimming and washing of beef carcasses as a method of improving the microbiological quality of meat. J Food Prot 1996; 59: 751-756. https://doi.org/10.4315/0362-028X-59.7.751

[28] Novak JS,Yuan JT. Viability of Clostridium perfringens, Escherichia coli, and Listeria monocytogenes surviving mild heat or aqueous ozone treatment on beef followed by heat, alkali, or salt stress. J Food Prot 2003;66: 382-389. https://doi.org/10.4315/0362-028X-66.3.382

[29] Castillo A McKenzie KS, Lucia LM, Acuff GR. Ozone treatment for reduction of Escherichia coli 0157: H7 and Salmonella serotype Typhimurium on beef carcass surfaces. J Food Prot 2003;66:775-779. https://doi.org/10.4315/0362-028X-66.5.775

[30] Novak JS, Yuan JT. Increased inactivation of ozone-treated Clostridium perfringens vegetative cells and spores on fabricated beef surfaces using mild heat. J. Food Prot 2004; 67: 342-346. https://doi.org/10.4315/0362-028X-67.2.342

[31] Cho Y, Muhlisin J H C, Hahn TW, Lee SK. Effect of gaseous ozone exposure on the bacteria counts and oxidative properties of ground hanwoo beef at refrigeration temperature. Korean J Food Sci An 204; 34: 525-532. https://doi.org/10.5851/kosfa.2014.34.4.525

[32] Kammer, R. The Microbial Killing Effect of Airborne Ozone. Examination Project Work, Department of Chemistry and Biomedical Sciences University of Kalmar 2005; SE-391: 82

[33] de Boer H E, van Elzelingen-Dekker CM, van Rheenen-Verberg C M, Spanjaard L. Use of gaseous ozone for eradication of methicillinresistant Staphylococcus aureus from the home environment of a colonized hospital employee. Infect. Control Hosp Epidemiol 2006; 27: 1120-1122. https://doi.org/10.1086/507966

[34] Burgassi, S., Zanardi, I., Travagli, V., Montomoli, E, Bocci V. How much ozone bactericidal activity is compromised by plasma components? J Appl Microbiol 2009; 106:1715-1721. https://doi.org/10.1111/j.13652672.2008.04141.x

[35] Song $M$, Zeng $Q$, Xiang $Y$, Gao L, Huang J, Huang J, Lu J. The antibacterial effect of topical ozone on the treatment of MRSA skin infection. Mol Med Rep 2018; 17, 2449-2455. https://doi.org/10.3892/mmr.2017.8148

[36] Strasser J H, Graham, D M, Mannapperuma JD, Enzweiler RJ. Membrane Filtration and Ozonation of Poultry Process Water. The Southern Conference on Avian Diseases, $43^{\text {rd }}$ Annual Meeting January 2002; 15: 157

[37] Graham D M, Strasser, J, Manipuri, J. D. Applications of Ozonation and Membrane Treatment in Poultry Processing, In Plant Evaluation of Pre washing Chickens with Ozonated Water, Ultrafiltration of Poultry Chiller Overflow for Reuse, and Ozone as Anti-Microbial Agent in Chiller Bath. Public Interest Energy Research Program California ; Energy Commission 2002; 95814.

[38] Kanaan, M.H.G. Antimicrobial Efficiency Of Ozonated Water As An Intervention Against Food-Borne Pathogen Campylobacter jejuni Contaminating Chicken Meat. Doctoral Dissertation College of veterinary medicine /University of Baghdad. 2017. 